\title{
せっかくのチャンスをふいにするのか？
}

\section{A missed opportunity?}

Nature Vol.437(595-596)/29 September 2005

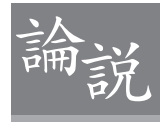

日本の首相にとって、国内の疲弊した科学技術制度を改革する貴重なチャンスが訪れた。

9 月に行われた日本の総選挙で与党の自由民主党が圧勝した ため、外観上は、小泉純一郎首相に対し、国内の諸制度を改 革する明確な権限が与えられたようにみえる。そのため、今 日の業績が将来の日本の技術的、経済的競争力につながる大 学や科学技術関係機関が改革対象リストのトップ近くにある と期待するのは、ある程度当然のことと思われる。しかし残 念なことに、このめったにないチャンスをつかもうとする兆 しがほとんどみられないのである。

日本の科学技術インフラの基礎が敷かれたのは、第二次世 界大戦から 20 年後のことで、その当時の日本は、急速な工業 化に著しい成功を収めていた。質は高いが、きわめて保守的 な大学制度、国内向けの政策と優先課題を積極的に打ちだし ていったパワフルな官僚組織、そして卓越した技術の代名詞 となった数社の大企業によって独占された強力な工業研究部 門が、工業化の 3 大要素であった。

このように並はずれた要素の組み合わさった日本の科学技 術制度は、他の多くの国々がうらやむほどのものだったが、 21 世紀は、これでは十分とはいえない。スケールと広がりの 点でどんなに優れていても、日本の科学研究を次のレベルに 引き上げること、あるいは将来の経済成長の起爆剤となる、 たとえばバイオテクノロジーやコンピュータソフトといった 分野の拡大展開を促進するうえで必要とされる柔軟性に欠け ている。経済以外の面でも世界をリードすることを志す現代 の日本にふさわしい環境や公衆衛生といった研究分野を支援 するようにできていないのだ。さらに、現在の科学技術制度で、 日本政府は、鳥インフルエンザ、地球温暖化から大規模研究 施設の建設といった諸課題についてアジアで抒抏いに必要と されている地域的なリーダーシップを発揮するために必要な 科学的ノウハウが得られないことも実証されている。

ところが、上述した論点は、いずれも選挙戦での争点とは ならなかった。これは別に意外なことではない。日本の政治 では、欧米の政治における「論点」を中心に動くことはまれな のである。ただし、今回の総選挙は例外的で、世界最大の金 融機関である郵便局の改革に関する小泉政権のプランが争点 となったのであった。政治家は、通常、自らの選挙区のため に予算を獲得することだけに力を注ぐ。一方、キャリア官僚は、 2 年ごとに担当部署が変わる制度のもとにあり、成果を挙げる ことよりもミスを出さないことに気を配る者すらいるのだ。
科学研究は、主に地方での予算支出の一形態として、政治 家にも官僚にも人気が高く、抒いい支持されてきた。しかし、 統治 (ガバナンス) には、あまり気を配ってこなかった。日本 の科学研究が、期待したほどの成果を生んでいない理由の 1 つは、これである。

日本では、重要な科学的課題に関する政策が密室で決まっ てしまうことが、あまりにも多い。その後、公聴会が行われ、 決定が下されるのである。その内容が明確なことはまれで、 実施についてはだれも責任を負わないようになっている。た とえばヒト胚性幹細胞研究の場合、研究者はこの研究を行う 権利があるといわれていたが、煩雑な手続にじゃまされて、 実際の研究はほとんど行われていない。

本物の改革断行内閣であれば、何ができるだろうか。まずは、 科学研究の原点である大学からはじめて、終身職も下位職も 若手、女性、外国人研究者に開放することを優先課題とする ことだろう。また研究年数に報いるのではなく、創造力を奨 励する評価システムも導入できるだろう。昨年、長年の懸案 だった大学改革の一部が実施に移されたが、上述したような 課題にはたいした影響は与えないだろう。

日本政府は、米国の研究公正局に似た部署を新設して、研 究者の行動を取り締まるべきである。そして、政府の諮問機 関である日本学術会議と科学研究予算に影響力のある総合科 学技術会議の強化を図り、国の大きさと経済力に見合った科 学技術政策を立てられるようにすべきである。そして、一般 の官僚が占めているポストの一部を研究者、あるいは元研究 者に譲り、苦闘するポスドク学生のためのキャリアパスを開 くべきである。現在のところ、文部科学省、特許庁や主要な 科学研究費補助金給付機関では、専門知識を備えたスタッフ の数が不足している。

そうすれば、日本は、鳥インフルエンザや地球温暖化のよ うな論点に関して、アジア太平洋地区で欠けているリーダー 的役割を果たせるようになるだろう。そして共同研究を使って 中国、韓国など近隣諸国との関係を改善できるかもしれない。

小泉首相が、これらの政策を実施に移す気配は、ほとんど ない。しかし小泉政権が、科学研究に対して中途半端な取り 組みを続けるかぎり、日本は科学的業績とアジアでの政策的 リーダーシップの両面で、その能力以下の貢献しかできない だろう。 